\title{
11 Russian Orthodox icons of Chernobyl as visual narratives about women at the center of nuclear disaster
}

\author{
Elena Romashko
}

Ten years after the Chernobyl nuclear explosion, in 1996, a crowd gathered in the city center of Minsk, Belarus. It was the annual political demonstration in remembrance of the disaster, the Chernobyl Way (Charnobyl'ski shljab). One participant was an icon painter, who carried his massive icon of Chernobyl in front of the crowd. The icon depicts the Virgin Mary and her son, both surrounded by the rays of the nuclear explosion. Behind her, the radiation sign overshadows the sun and the inscription below reads in Belarusian "Mother of God of the Victims of Chernobyl." A law enforcement officer beat the icon painter in the face with a baton, injuring his eye. Even today religious items serve as crucial elements of this annual demonstration. In 2017, two men carried the same icon from the 1996 demonstration through the city of Minsk. The icon was adorned with a Slavic ritual cloth embroidered with traditional symbols. In front of them was a priest in a cassock holding a silver hand cross. On the right a man carried a flag with the inscription "Belarusian Autocephalous Orthodox Church." Two men with a church bell on a crossbar led the procession. Parts of a secular political demonstration were reminiscent of a religious procession.

In 2016, an art gallery in Minsk held an exhibition in remembrance of Chernobyl. A woman stood in front of the series of paintings commemorating the disaster. Her glance stopped at a somber painting of two angels with black wings holding the dead body of a child, they pass him, pale and ready for the burial rites, to his mother. The caption reads "Madonna of Chernobyl." She is the Mother of God, her son is God who suffered and died for others, but he is also a child who never grew up.

In the past 30 years, the imagery chosen to depict the events of Chernobyl tells more than the story of the reactor rupturing and emergency workers dying from radiation sickness. It tells a story of Mary caught in the center of the nuclear explosion. It tells a story of Jesus, who dies as a child, implying that God incarnate can be defeated by the power of radiation.

To commemorate the worst nuclear disaster in history is not an easy task. The Chernobyl disaster revealed a new set of challenges of the nuclear age: fluidity, omnipresence, and the extended temporality of nuclear contamination (see Morton 2010). These are difficult to comprehend and even 


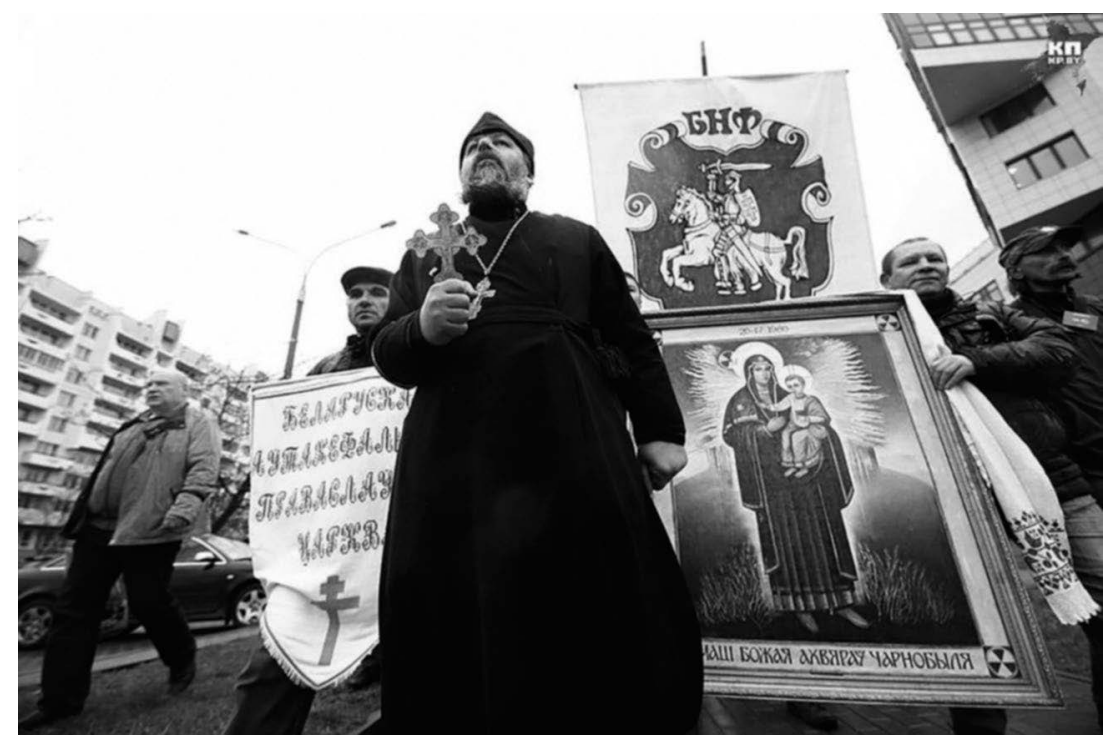

Figure 11.1 The icon "The Mother of God of the Victims of Chernobyl” is carried through the demonstration Chernobyl Way in 2017. Photo Pavel Martsinchyk, icon painter Alexei Marachkin.

more difficult to depict. Since the disaster religious actors, imagery, and content have had a significant presence within the commemorative culture of Chernobyl.

This 30-year-long tradition of Chernobyl commemoration, which makes use of Russian Orthodox iconography and religious-themed art as a medium to transfer the grief of Chernobyl in post-Soviet space, is my research interest. The striking prevalence of religious imagery dealing with the disaster has not received enough attention in the academic research of nuclear culture, especially in the post-Soviet space. My research aims to fill in this gap through an investigation of the religious elements of the memorial art and Russian Orthodox iconography of Chernobyl as sources for discovering the post-Chernobyl nuclear culture.

This chapter stems from my ongoing broader study of material religion and female agency in the process of coping with the consequences of contamination in Belarus. I conducted fieldwork in Minsk between 2014 and 2019 over several trips, totaling ten months in the field. Besides collecting and analyzing artwork, I gathered a number of narratives through participant observation and in-depth interviews with people who had different attitudes to and involvement in the post-Chernobyl agenda. I asked the interviewees to interpret and discuss icons and artworks dedicated to the Chernobyl disaster and share their personal experiences of the tragedy as well as their everyday and religious life after it. Most of the interviews were 
not recorded, as the respondents refused permission, demonstrating distrust in anyone gathering information about politically controversial topics as well as hesitation and often refusal to give their own opinion regarding religion or belief without the permission or supervision of a priest or spiritual father. ${ }^{1}$ Therefore, to interpret visual reflections of the disaster and to fill in the gaps of personal narratives, I draw on the work of Svetlana Alexievich, who won the Nobel Prize in literature in 2015. She brings together oral histories of the disaster in her book Chernobyl Prayer ${ }^{2}$ (Alexievich 2016).

In this chapter, I investigate how the nuclear events of Chernobyl are perceived by lay people and reflected through the medium of Orthodox iconography. I pay particular attention to how these icons approach gender roles, and the place and meaning they assign to the agency of ordinary women and men whose lives were affected by the Chernobyl disaster.

Gendered imagery is a distinct characteristic of the commemorative culture of the Chernobyl disaster. I analyze four images. Painters often depict women to commemorate the Chernobyl disaster, especially through the image of the Virgin Mary, as present in the "Madonna of Chernobyl" and the "Mother of God of the Victims of Chernobyl." In contrast, public commemoration, by the state and often the Church, honors almost exclusively military men and male members of the rescue forces. This contradiction can be seen in the third image, "The Savior of Chernobyl" and its artistic modifications. The fourth and last image, "Christ Blessing the Children," is addressing congenital diseases affecting current and future post-Chernobyl generations. This icon avoids the depiction of gender roles after the disaster by showing both men and women as sick and suffering children asking for a blessing.

\section{Impact of the Chernobyl disaster}

The magnitude of the Chernobyl disaster in 1986 staggered the world, with the realization that the industrial use of nuclear energy can be as harmful to humanity as the earlier nuclear bomb in military use. In contrast to the intentional bombing of Japan in the end of the Second World War, in Chernobyl an unfortunate chain of events triggered the power of the split atom to bring destruction and contamination. However, the government of the Soviet Union considerably aggravated the consequences, as it mismanaged the disaster, attempted to silence discussion of it, and avoided informing the affected population about the appropriate safety regulations. This massive nuclear disaster on the border of the Ukrainian and Belarusian Soviet Republics permanently changed the lives of their residents.

For the Belarusian people, the consequences of the explosion were devastating: contamination of almost a quarter of the territory with numerous types of radioactive materials as well as the evacuation and relocation of about 340,000 people (Bashilov 2013, 4). Many locals feel victimized and deceived by the authorities, and continue to suffer from a range of health issues that are attributed to radioactive contamination. This sentiment is crystallized in an interview collected by Svetlana Alexievich (2006, 193-195): 
People talk about the war, the war generation, they compare us to them. But those people were happy! They won the war! It gave them a very strong life-energy, as we say now, it gave them a really strong motivation to survive and keep going. They weren't afraid of anything, they wanted to live, learn, have kids. Whereas us? We're afraid of everything. We're afraid for our children, and for our grandchildren, who don't exist yet.

Radiation presents a unique challenge for religious thought, as it is "invisible, tasteless and odorless" (Phillips 2002, 30). It has no boundaries; it can penetrate and possess human bodies, objects, and places. Some radionuclides have an extremely long lifespan and are able to harm multiple generations of people, either directly through the food and environment or indirectly through various inherited genetic mutations. All these characteristics of radiation provoke associations with supernatural forces, divine providence, or demonic powers (Romashko 2016). Svetlana Alexievich (2016, 58) writes:

I see Chernobyl as the beginning of a new history: it offers not only knowledge but also prescience, because it challenges our old ideas about ourselves and the world. (...) Chernobyl is, above all, a catastrophe of time. The radionuclides strewn across our earth will live for 50,000, 100,000, 200,000 years. And longer. From the perspective of human life, they are eternal. What are we capable of comprehending? Is it in our power to extract and decipher the meaning of this still unfamiliar horror?

The ability of radiation to take away everything one values, such as land, health, and loved ones, resulted in a tendency to correlate it with sin and evil in Russian Orthodox sermon rhetoric, newspapers, and popular magazines. Moreover, both the head of the Russian Orthodox Church, Patriarch Kirill of Moscow, and the Patriarchal Exarch of All Belarus, Metropolitan Philaret, regarded human sin as a reason for the Chernobyl disaster and part of God's providence (Vakhromeev 1994; Religious Information Service of Ukraine 2011).

It is not surprising that diverse layers of symbolic religious imagery have been used to give meaning to what happened in Chernobyl. Religious ideas became leitmotifs in artistic perceptions of Chernobyl, Russian Orthodox iconography, people's narratives, and vernacular belief.

\section{Framing the religious dimensions of Chernobyl}

The ambiguity of nuclear power, capable of driving human mistakes to an unthinkable level-the extinction of humankind-rapidly ran through different levels of culture (see Boyer 1985; Aho 1989). I suggest that although the religious dimension is often overlooked it is still deeply integrated into 
nuclear culture. People use religious texts and imagery to respond to the nuclear events, they resort to them in their attempts to control, represent, and resist nuclear power (see Hogg 2016, 7).

In the Soviet Union, a response to the nuclear disaster of Chernobyl and its precarious consequences was achieved through the production of commemorative visual art. The ideological nature of the Soviet period can explain the choice of this particular form. The religious connotations of the nuclear culture could not be spoken of in the pronouncements of the officially atheistic state. However, ordinary people, including local artists, actively used traditional and religious symbols to comprehend and depict the impact of the nuclear disaster.

For example, the image of storks, as a local folklore symbol related to vegetation, procreation, migration, and peaceful coexistence with nature, was widely used in the illustrations of the Chernobyl disaster. Storks appear in numerous schoolchildren's drawings when they are asked to express their perception of the Chernobyl disaster (see Danilenko 2011). A Chernobyl monument in Kyiv, at the Church of St. Theodosius of Chernigov, depicts storks falling down dead, trapped into the orbit of an atom encircled with the inscription "For the dead, living and unborn." This memorial church was founded to conduct commemorative services for the Chernobyl victims and serve as a visual monument for the Chernobyl disaster. The facade is decorated with a massive mosaic of "The Savior of Chernobyl," the most famous Chernobyl icon. Chernobyl memorial churches and Chernobyl icons rapidly appeared in different parts of Ukraine, Belarus, and Russia. For example, in Minsk alone there are three Russian Orthodox churches dedicated to the memory of Chernobyl and two of them are among the biggest churches in the city. Chernobyl memorial churches are spreading across the geographical and denominational borders: the newly built Belarusian Greek-Catholic Church consecrated in 2016 in London is also dedicated to the Chernobyl tragedy.

\section{Russian Orthodox icons of Chernobyl}

The Chernobyl icons, devotional images of Christ or the Virgin Mary in relation to the Chernobyl nuclear disaster, were officially blessed by the Orthodox Church and given special liturgical veneration. Nevertheless, they are not well known among Russian Orthodox believers, even though they are rapidly spreading throughout the post-Soviet territories. Chernobyl iconography has developed over the last 30 years, and the icons can be seen in a number of churches in the post-Soviet region. One of these, "The Savior of Chernobyl," was put into mass production as an affordable laminated copy, which enabled people to bring it to their homes, put in their wallets, and keep it at their workplaces. Some Chernobyl icons are unique exemplars while others come in multiple variations. 
Chernobyl icons and memorial churches are often claimed to be the result of a collective vision or an individual dream supported by a number of enthusiasts who eventually negotiated the formal blessing from the official church. Chernobyl icons are predominantly ordered by local initiatives tightly connected with Chernobyl survivor NGOs and unions formed to assert the rights and financial benefits of members of the Defence and Rescue Forces or "liquidators." 3 The icons of Chernobyl are also given as formal gifts to commemorate nuclear disasters on the international level. The Ukrainian Chernobyl Union sent a replica of "The Savior of Chernobyl" to the people of Japan in 2011 and the Ukrainian President Petro Poroshenko gave a replica of the same icon to the church in Liaskovichi during his visit to Belarus in 2017. The icons were given not only to churches, but to museums and theaters as well. The Chernobyl icons are consecrated in the Russian Orthodox Church, but it is often suggested that they can be venerated by believers of other denominations and religions, as nuclear disaster is seen as a global tragedy and therefore a unifying factor locating these artifacts in the ecumenical domain.

The combination of folk and official forms of the Chernobyl icons can be seen as expressions of vernacular religion (Primiano 1995), which acknowledges the importance of the local and contextual expression of beliefs. Bowman and Valk argue that vernacular religion is a methodologically useful and ethically appropriate concept to describe practices located outside official church dogmatics. It helps to avoid approaching them as "pagan" traditions or misinterpretations of the "correct" teaching (Bowman and Valk 2012, 3-7). Moreover, vernacular religion connects local beliefs with specific historical, social, political, and ecological conditions in which religious beliefs and practices exist, interact, and are reinterpreted, which is crucial to Chernobyl spirituality.

According to Marion Bowman, vernacular religion includes three components of religion-official (related to the institutionalized religion, theological teaching, and hierarchy), folk (related to the commonly accepted and transmitted belief and practice, regardless of the institutional position), and individual (related to the personal interpretations of folk and official ideas gained from experience) as well as their interconnections (Bowman 2004, 6). Therefore, vernacular religion is not another term for folk religion, but an attempt to include the "folk" and "personal" elements as an integral part of religion as it is lived. Multiple interviewees characterized the Chernobyl icons as "obviously folk" and therefore "inferior" or "wrong."

Next, I analyze in more detail four artworks from the perspective of vernacular religion. First, the paradigmatic painting "Madonna of Chernobyl" by Mikhail Savitsky. After that, I analyze three icons officially sanctified by the Russian Orthodox Church: "The Mother of God of the Victims of Chernobyl," "The Savior of Chernobyl," and "Christ Blessing the Children." 


\section{The Madonna and mothers of Chernobyl}

Mikhail Savitsky is a renowned Belarusian painter and cultural symbol. He was born in 1922, served in the Second World War, and was captured and imprisoned in concentration camps in Buchenwald, Dachau, and Dora during his service. After the war he studied art and became well known for his monumental paintings. In 1988-1989, Savitsky created a series of paintings dedicated to the Chernobyl catastrophe with the title "Black verity," including the "Madonna of Chernobyl." This painting came to symbolize the Chernobyl disaster in Belarus.

The painting links the consequences of the disaster with the image of Mary. Even though it does not serve as a religious icon, it became culturally iconic, as it established the connection between the mourning Mother of God and ordinary women coping with the nuclear crisis. The composition of the painting resembles an overturned cross. It is a farewell: at the top of the cross stands a female figure dressed as a countrywoman who is passing the body of her naked dead son to two angels with black wings. The bodies of the mother and son form the vertical beam of the cross; the arms of the angels form the horizontal beam. The art critic Emma Pugacheva highlights the fact that there is no source of light on the painting, so the figures are shedding the light from within themselves. She characterizes this effect as giving "an impression of the Holy Ghost descending into this world of tragedy and grief" (Pugacheva 1991, "The Chernobyl Madona," para. 3).

This development in the representation of the nuclear culture of Chernobyl is important as it differs from the male-focused way the media and state officially commemorate the disaster. The power plant employees and liquidators were predominantly male. They formed the liquidator NGOs, fighting for their rights and disability benefits. Commemoration of the events was not much different: military men were venerating their comrades-in-arms. Chernobyl was always presented in the public sphere as a male prerogative, even in monuments; a male figure is always depicted in the middle of the explosion. Russian Orthodox memorial services with male priests and deacons reading the list of male names of dead liquidators do not challenge this tradition. Within the domain of official Russian Orthodox religion men are the heroes, martyrs, and survivors of Chernobyl, while women are victims and mourners. Even though Savitsky placed a woman at the center of his Chernobyl commemoration, he still perpetuated these traditional roles. The Mary of Savitsky is depicted eyes downcast, calm, and outwardly restrained, as an obedient and helpless mourner.

"The image of Madonna is an eternal embodiment of love and regeneration of life, however, along with that she has always personified the drama of sacrifice that comes with it," states Pugacheva (1991, "The Chernobyl Madona," para. 1) in her analysis of the painting. Rima Nasrallah draws a similar conclusion in her analysis of the iconographic depictions of Mary in Orthodox churches, when she claims that "a highlight of this suffering 


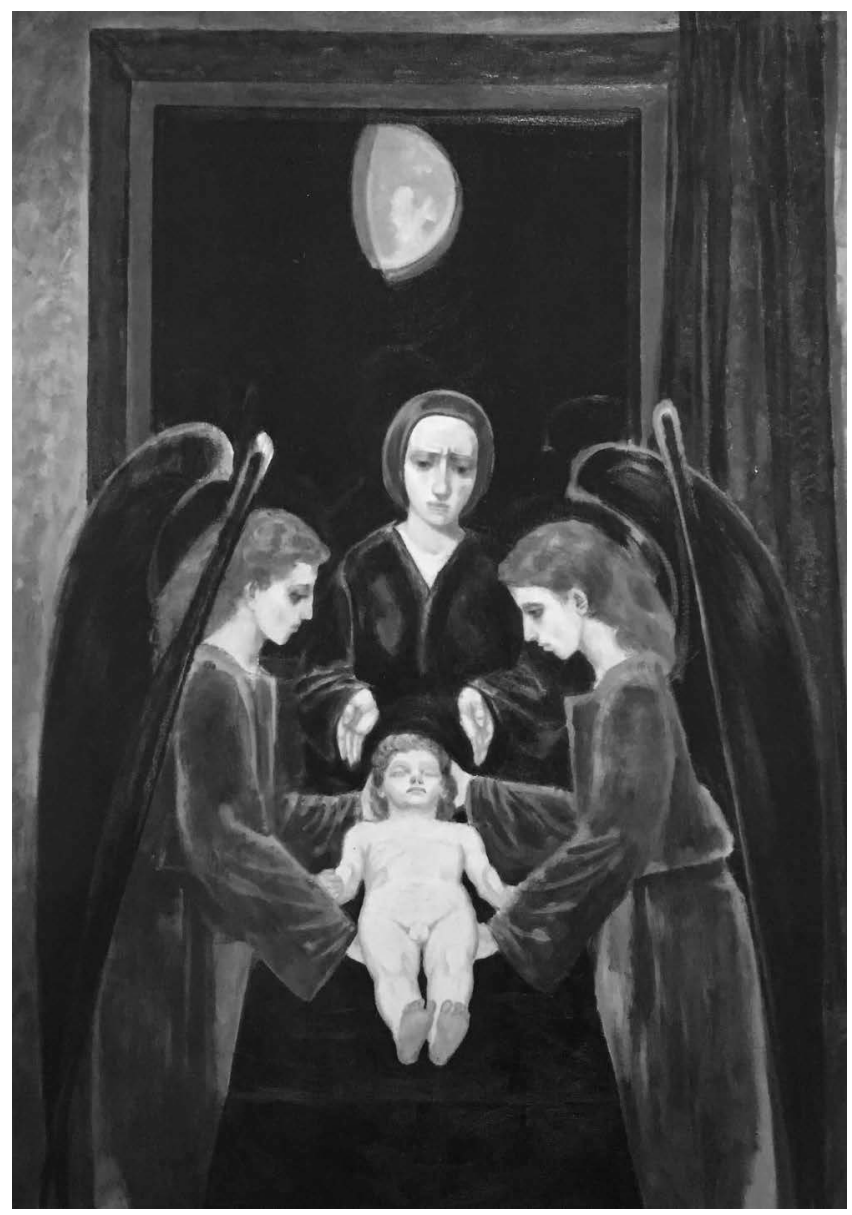

Figure 11.2 “The Madonna of Chernobyl” by Mikhail Savitsky. The Gallery of Savitsky / Photo Elena Romashko.

is that Mary did not choose to suffer as a heroic act but because of the relationship she had with the one to whom violence and injustice were being done" (Nasrallah et al. 2016, 17).

In the case of Chernobyl, the injustice is toward the children who die too young and suffer from genetic illnesses and cancer. The mother acts here as an advocate for her vulnerable child. Therefore, in difficult economic conditions, local women see the agency of the caregiver as an active and ultimately sacred female duty.

This could explain why Belarusian artists often depict Mary surrounded by the horrors of the nuclear tragedy and envisaged as an average contemporary woman exposed to radiation, with an endangered, sick, or sometimes even dead child. These allusions are not allegorical but taken from the 
actual events after Chernobyl. The former chief engineer of the Institute for Nuclear Energy, who participated in trips to the Chernobyl area to assess the consequences of the disaster, reported:

There was a woman in our group, a radiologist. She became hysterical when she saw that children were sitting in a sandbox and playing. We checked breast milk-it was radioactive. (...) We saw a woman on a bench near her house, breastfeeding her child-her milk has cesium in it—she is the Chernobyl Madonna.

(Alexievich 2006, 161-163)

I believe that sensitivity to infertility issues and the power of radiation to cause congenital and genetic diseases in children born after the disaster are the key reasons for the mass appeal of the image of Mary with a child in secular art. This portrayal aims to depict the reality of everyday life for Belarusian women. At the same time, it unfortunately conveys and upholds the message that caring for the "damaged children" of Chernobyl is not a family duty but rather the concern and responsibility of the mother alone. Other paintings by Victor Barabantsev and Yuri Nikitin are similar to the one by Savitsky. Some other painters use images of Mary (Gavriil Vaschenko, Alexander Kishchenko), Marian icons (Vladimir Gordeenko, Vladimir Kozhuh), or women and mothers (Vladimir Kozhuh, Victor Shmatov, Sergey Davidovich). It is noteworthy that all these are painted by male artists and, though they use images of women to depict the disaster, they overlook the actual agency and actions of women coping with contamination. Often, a woman seems to be seen as a metaphor of vulnerability, innocence, procreation, obedience, and resignation.

Such images of Mary can hardly be included in official Orthodox practice as icons because of their noncanonical style and ideas, unlike the ones I deal with in the next section. Nevertheless, these artworks occupy an important place in the cultural memory of the post-Chernobyl territories and Belarusian national history. Moreover, they support traditional Orthodox roles assigned to women coping with the Chernobyl disaster. Perhaps these roles result from a sociopolitical construction that propagates obedience and passivity, not only as an expected feminine duty but as applied to the nation as a whole. Chernobyl, when seen as a result of the mismanagement of a totalitarian state, can evoke opposing responses. Alongside acceptance and mourning, there is resistance and protest.

\section{Mary resisting radioactive contamination}

The first officially consecrated Chernobyl icon, "The Mother of God of the Victims of Chernobyl," was made in 1990 by Aliaksiey Marachkin. This icon was officially recognized by the Russian Orthodox Church, and the original is in a chapel in Zhodino, Belarus. A copy of this icon is present at 
the Chernobyl Way. These duplicate icons have surprisingly opposite destinies to the original one, which is isolated from the believers behind the iconostasis at the altar, in the part of the church where only priests and men with special permission are allowed to go. The other one, the duplicate, leads the march of the political opposition to remind people about Chernobyl and how important clarity and transparency are for civil society. The artist explains:

The icon suffered as well as those who carried it. There are spots of blood on the icon, as a reminder of the violence during the dispersal of demonstrations. The policemen tried to take it away, they wanted us to forsake it, and throw it away, they hit our hands (...) This is a powerful symbol not only of the Chernobyl demonstrations, but in general, it is a symbol of the spiritual awakening of people after terrible suffering.

(Kirkevich 2017)

The fact that the icon is being used more for political reasons than for prayer and veneration is a peculiar aspect of the history of Chernobyl iconography. The icon has a unique apocalyptic symbolism expressed through radiation-related symbols. At its center is the Mother of God with a child on her arms standing on grass resembling wormwood. ${ }^{5}$ Behind her back are the rays of the Chernobyl explosion and a sun overshadowed with the radiation symbol. The people of the contaminated territories are gathered under the explosion.

The iconography of "The Mother of God of the Victims of Chernobyl" is influenced by the iconographic tradition of depicting The Woman of the Apocalypse on Russian engravings, which had a direct political function. The depiction of the Virgin Mary as the Woman of the Apocalypse above clashing armies was used to praise military victory and emphasize divine patronage over the Russian army. The foreign army, for its part, was depicted among the demonic powers of hell (Pogosjan and Smorzhevskih 2002). Similarly, the icon "The Mother of God of the Victims of Chernobyl" can be interpreted as depicting the victory over the demonic power of totalitarianism and radioactive contamination.

Compared to Savitsky's painting, Mary in Marachkin's icon is strikingly different: she is powerful; the radioactive explosion stays behind her not harming her or Jesus; she is envisioned as the eternal ultimate power resisting the contamination. The icon provides hope for the triumph over evil and support to those who choose to resist evil with her. She could be seen also as the symbol of the church: "I will build my church, and the gates of hell shall not prevail against it" (Matthew 16:18).

The resistance of the Christian Church against radiation is, perhaps, the most common connection between religion and Chernobyl. Low radiation levels inside the churches in the Exclusion Zone ${ }^{6}$ are claimed to be a miraculous occurrence (see Kotrelev and Shapkin 2007). Pilgrims and journalists 
narrate that the level of radiation in the Church of the Prophet Elijah in Chernobyl is lower than in Moscow or Kyiv.

However, there is a certain resistance toward the icon "The Mother of God of the Victims of Chernobyl" among believers. Some struggle to accept the political agenda behind the use of the icon, while others criticize its lack of traditional Orthodox iconographic traits. In her reaction to this icon, Lidia (interviewed 2015), a parish member of the main cathedral in Minsk, said "I think this icon is definitely not canonical. I would rather call it a spiritual artwork. I would not accept such an icon in the church during Liturgy." The case of this icon clearly illustrates that Chernobyl icons are honored by specific groups of people. Political activists participating in the Chernobyl Way, who mostly represent opposition to the current government, recognize the icon as their own sacred object. Yet they do not pray in front of it, but demonstrate it, bring it to the public sphere as an attempt to draw attention to its message. They bring both the idea of the church resisting radiation and totalitarianism and an image of a woman with her child to the center of the unofficial Chernobyl commemorative culture. In this sense, the Chernobyl Way serves as a window on alternative commemorative expressions presented as public performances.

\section{Jesus Christ the Savior of Chernobyl}

My third image, "The Savior of Chernobyl" 7 was created in 2003, and arguably became the most well-known Chernobyl icon. Yuri Andreev, president of the NGO Chernobyl Union of Ukraine, had the idea for this icon. According to numerous Russian Orthodox websites and articles, he saw this image in a dream and later was granted permission by the head of the Ukrainian Orthodox Church, Metropolitan Vladimir, for such an icon to be painted by the monks of Kyiv Pechersk Lavra (Archmandrite Sergiy 2016). In 2004, its veneration was officially allowed by the Russian Orthodox Patriarch, and in 2006, the original was given to the Church of the Prophet Elijah in the Exclusion Zone.

This icon initiated a new type of Chernobyl iconography. Across postSoviet space new icons under the name "The Savior of Chernobyl" are being created (Novosibirsk (2008), Tomsk (2009), Bronnitsy (2010), Omsk (2011), Moscow (2012), etc.). Some of these look like copies of the original Kyiv icon, while others modify the iconography and composition to the extent that they can only be recognized as versions of the same icon through their name.

The original Kyiv version is set in a floral frame with a distinctive difference of iconography in the upper and lower part of the icon. The upper part is set on a golden background, with Jesus shown within a mandorla in the middle. On his left is the Mother of God, and on the right the Archangel Michael. In the centre of the lower part is a trident-shaped tree surrounded by burned land. On the right stands a group of liquidators in their uniforms: 
a firefighter, a power plant employee, a pilot, a doctor, and a nurse. To the left of the tree stand faceless figures in white robes symbolizing the victims of the Chernobyl disaster. On the horizon is a falling star over the outline of a nuclear power plant.

The trident shaped tree is an image of a real tree nearby the Chernobyl power plant, which became one of the dreadful apocalyptic symbols of Chernobyl. The tree is similar to the cross and to the trident, the emblem of Ukraine. According to a legend, during the Second World War Nazi soldiers hanged people on that tree and their martyrdom gave the tree miraculous power. Another apocalyptic symbol is the falling star Wormwood, a reference to the last book of the Bible:

The third angel sounded his trumpet, and a great star, blazing like a torch, fell from the sky on a third of the rivers and on the springs of water-the name of the star is Wormwood. A third of the waters turned bitter, and many people died from the waters that had become bitter.

(Revelation 8:10-11, NIV)

In this passage in Ukrainian, the name of the fallen star resembles the word Chernobyl ("chernobil"), which can be translated as absinth grass, wormwood, or mugwort. Its bitterness made the herb a powerful source of metaphors in the Biblical context and beyond. A star, blazing like a torch, is frequently compared to the explosion, while bitter waters and a curse to the third of the rivers resembles a significant part of Belarus being contaminated.

The reaction to this icon has been ambivalent, both regarding its content and iconography. The obvious distinction between the upper part of the icon depicting Christ and the Virgin Mary and the lower part showing ordinary people in uniforms and gas masks was described by one of my informants, a priest and icon painter (interviewed 2015), as "a tasteless compilation." The depiction of the nuclear reactor or uniforms on the icon was often interpreted by interviewees as intolerable, "ridiculously standing out," and a reason to create new versions of this icon to "correct" it. Marina (interviewed 2015), a member of a church youth organization, told me, "I would cut this icon in half, with the upper part I could pray, I would remember Chernobyl and pray for the victims and the deceased, I don't need particular details of the lower part for it." Yuri Andreev (2010), who initiated the icon to be painted, has responded to the public critique by noting that "our spiritual relic, the icon "The Savior of Chernobyl" is not recognized only by heretics and heathens as it was canonical even before it was made."

The inconsistency between the upper and lower part of the icon and the compilation of individual, official, and folk elements in it could explain the need for this icon to be reinterpreted, changed, and remade to satisfy the needs of different religious groups. 
Some variations of "The Savior of Chernobyl" aspire to look more canonical and less centered on apocalyptic visions and elements of folk religious tradition. For example, by comparing the Kyiv (2003) and Moscow (2012) variants of the icon, one can see the change in the painting style, the central image and characters, and therefore the content and message. The Moscow icon is made in the Byzantine style. The Chernobyl pine has been replaced with a generic tree, while the building of the power plant has been moved to the foreground. With this change, the folk religious symbol is removed from the icon and replaced with an image resembling the historical Chernobyl power plant. The uniforms of the liquidators are replaced with canonical garments-the cleanup workers from the original icons are replaced with warriors in Byzantine army vestments. Through this, the military conscription to the Chernobyl cleanup is reinterpreted as a holy duty and service in "Christ's army." Those who died are seen as martyrs of the nuclear age regardless of their personal belief or denomination.

Some of my informants who accepted the original Kyiv iconography of "The Savior of Chernobyl" were extremely critical and unwilling to accept this Moscow version, which they described as "unrealistic." "Did Chernobyl happen in Israel? If we would show this icon to a liquidator of the Chernobyl disaster, he would say that he wore different kind of clothes" Vladimir sarcastically commented during a group interview (2015) with members of a church youth organization. He added, "it seems that this icon depicts a reactor built by aliens and after a few centuries was found by humans."

The most striking changes to the iconography of "The Savior of Chernobyl" involve the depiction of the female characters. The female nurse and doctor among the liquidators in the Kyiv icon (2003) are removed from the Moscow icon (2012). Faceless souls of the people who died as a result of the Chernobyl accident are given faces. The figure of a mother with a child is placed in front of them on the Moscow icon. This change, while preserving a female image, changes its content-a woman who was active on the side of the liquidators is replaced by a passive suffering image. Her agency is changed, her professional help and voluntary sacrifice of her own health for the sake of others substituted with a more traditional female role-motherhood.

Vernacular religion is conceptually valuable because "it highlights the power of the individual and communities of individuals to create and recreate their own religion" (Primiano 2012, 383). This aspect of vernacular religion can help to conceptualize women's agency in the post-Chernobyl context.

Not all of the subsequent versions of "The Savior of Chernobyl" reduce the female roles to motherhood only. In the variation of the icon made for a church in Tomsk in 2009, the original plot and composition of the icon are significantly altered and ecological and broader cultural themes are emphasized. Liquidators and sufferers are united in the left corner of the icon, and two new characters join them-a rural couple in traditional clothes, signifying grief over abandoned farmland, together with the folklore and 
traditional culture of the rural settlements, which vanished due to the sporadic resettlement of the evacuated population. The Tomsk version (2009) of this icon, in other words, blurs the distinction between the victims and the survivors and depicts women in more roles than that of mothers, while remaining traditional and following the inclusive message of the original Kyiv icon (2003).

The depiction of the role of women in Chernobyl icons is tightly connected to how these icons deal with the Soviet past. Officially, representatives of the Orthodox Church often claim that atheism and idolatry of science were reasons for the Chernobyl disaster (Romashko 2016). During the Soviet period, women were actively involved in often physically demanding work on equal terms with men. Professional education and an occupation were as essential for women as for men. The refusal of the Orthodox Church to depict women's professional qualities, instead presenting them as mothers and caregivers, seems to be an attempt to establish Orthodox values and traditional gender roles as righteous and dignified in opposition to the Soviet ones. This aspect shows the difference between folk and official religious approaches to gender roles as an attribute of the past and to the traditional role of women.

The folk religious approach, as shown on the Kyiv version of "The Savior of Chernobyl," focuses on integrating and embracing the Soviet reality. From the folk religious view, in the Soviet era, religion in the public sphere was generally persecuted; many areas were left without churches and priests. This created space for local women to take on religious and quasi-clerical roles and they integrated elements of the traditional culture into their practices. The official religion claimed that these elements were pagan, sprouting from the low catechetic levels, mundane needs, and desires of local people. Therefore, these folk "uneducated" and "inferior" religious practices were often perceived as female in opposition to the official "educated" clerical male practices.

The attempt to reduce the involvement and local religious power of women and to return clerical functions to men only using religious imagery might be one more reason for the desire of the official religion to reduce women's role exclusively to the private, domestic sphere. The iconography of "The Savior of Chernobyl" made for Moscow in 2012 represents the culmination of this tradition.

The inclusive depiction in the Kyiv version, highlighting different expressions of spirituality and interpretations of tradition, thus allowing for more female input, was eventually cut out when the icon acquired a more official status and was relocated to Moscow, associated with the domain of official religion and consolidation of the Russian Orthodox hierarchy.

\section{The "damaged" children of Chernobyl}

The concept of vernacular religion stresses how the narration of the same historical events can be reinterpreted differently on individual, folk, and 
official levels. Vernacular religion also reflects the different values and didactic messages that folk and official religious artifacts convey. It is typical for folk artifacts to combine religious and political power, which can serve as a tool of establishing justice and equality, as demonstrated through the agency of the above Chernobyl icons. But no less important is the ability of icons to console and heal.

The desire to be healed is met in the fourth Chernobyl icon named "Christ Blessing the Children" created in the Monastery of St. John the Baptist in Kazan in 2013. ${ }^{8}$ This icon has been made as an interpretation of the common iconographic motive referring to the New Testament passage about Jesus blessing children (Mark 10:13-16). The correlation between this passage and the Chernobyl disaster had previously been drawn by the German nun Angelina Heuser in her 1998 icon "Jesus Healing the Children of Chernobyl." The icon made in Kazan, however, differs in style from the work of Heuser, as it follows the Byzantine iconographic tradition.

While preserving the standard composition of the icon "Christ Blessing the Children," the Kazan icon adds a number of substantial alterations. At the center of this icon is Jesus Christ, seated and wearing blue garments with a golden band, his left hand raised in a blessing gesture. Christ is surrounded by children, boys and girls who are all wearing modern clothes and reaching their arms towards him. A bald child wearing a medical mask sits on his lap. To the left of Christ is a teenager using crutches. To the right, there is a group of sick children with a smaller child wrapped in bandages riding a rocking horse in front. In the background, there is a house on the left and a rock on the right; these form part of the standard composition of the icon "Christ Blessing the Children." However, between them stands a gray building of a nuclear power plant with a substantial crack running through the front cooling tower and the main building.

The biblical passage about Christ inviting children to come to him can metaphorically be understood as a blessing of the future generations who will suffer the consequences of the explosion. By depicting all the survivors as children, this icon does not suggest any gender-based difference in the request for healing and blessing. However, as mentioned above, fertility and the health of future generations represent one of the main concerns that women express in the post-Chernobyl world. As one of the informants of Svetlana Alexievich shares $(2006,193-195)$ :

The other day my daughter said to me: "Mom, if I give birth to a damaged child, I'm still going to love him." Can you imagine that? She's in the tenth grade, and she already has such thoughts. Her friends, too, they all think about it. Some acquaintances of ours recently gave birth to a son, their first. They're a young, handsome pair. And their boy has a mouth that stretches to his ears and no ears. I don't visit them like I used to, but my daughter doesn't mind, she looks in on them all the time. She wants to go there, maybe just to see, or maybe to try it on. 
In contemporary Belarus, long-term relocation to bigger cities is common among mothers whose children suffer from illnesses, perceived as related to radioactive contamination such as cancer. The fathers are often at work and the mothers take care of the other children at home. In many cases, families with a disabled child end up separating or the fathers resort to drinking, as happened with my informant Anna (interviewed 2016), who shared with me her experiences on raising a child with mental and physical disabilities in Belarus.

I found the monastery where I could take my daughter [to pray for healing] (...) My husband Oleg didn't want to go there. So I made him go, through extortion. I know people say it is bad. But I gave him a choice, either I will have him locked up at the LTP, ${ }^{9}$ or he comes for two weeks to the monastery. So this is how he came with us (...) I was of the opinion that I am a good person and Oleg is a bad one. He drinks, and so on. But there I realized that I was wrong. The wise monk [starets] did not say a word about my husband, but he said that it [the disease of Anna's daughter] happened because of me, because of my arrogance. He saw through us like on an X-ray. (...) During this trip I conceived my second [healthy] daughter, which is a miracle, considering how we live.

Anna told me that she would not be able to support her child without the church. She cannot work and her husband is often missing, drinking hard and does not bring money, nor does he help with the children. She was not familiar with the icons of Chernobyl, but was very curious to see them and find out more about them. She was very interested in any healing pilgrimage destinations. She expressed longing for the genuine paternal support, love, and warmth that her own father gave to her but her daughters did not have. She mentioned that she often gets this from priests, monks, and other men in positions of authority in the church.

It is a grim reality of the post-Soviet territories that women are often the only caregivers of their sick children and many children with disabilities are given into state care in orphanages. Parents are frequently left with no help from the government and facing numerous regulations that restrict and isolate children with disabilities from the public sphere. In the hope of support and consolation, people appeal not only to the Mother of God, but also to Jesus blessing the children. Drawing on my interview with Anna, I suggest that the icon "Christ Blessing the Children" addresses the issue of missing parent(s) and fulfills the hope that even children who are neglected or orphaned due to their disability are still protected and guided by Jesus.

The origin of the Chernobyl icon "Christ Blessing the Children" is claimed to be rooted in local believers' request for such an icon to be made. According to Father Nectarius, the current head of the Kazan Monastery of St. John the Baptist and a former liquidator, one of the monks saw a similar picture in a magazine, ${ }^{10}$ and decided to place it on a wall. He says: 
people have come to treat it very respectfully. And when we decided to remove it, to hang another icon, they began to ask: "Where is the picture?" The decision to make an icon dedicated to Chernobyl appeared naturally. Afterward, we began to respond to people that soon instead of that picture they will see the most authentic icon.

(Kirillova and Iskandirov 2014)

By transforming the picture from a magazine into an icon with a conventional iconographic name and a style associated with canonical iconography, the monks relocated the local venerative practice into the domain of official religion with its pre-existing format of Chernobyl commemoration. This did not go unnoticed by other engaged groups. The NGO of Orthodox liquidators, named after the Chernobyl icon "The Savior of Chernobyl," published an official letter critiquing the icon on the website of "The 'Chernobyl' Union of Russia", stating: ${ }^{11}$

It causes disappointment and frustration that the important symbols of Chernobyl, such as an icon (...) are created only on the basis of one's personal understanding of the issue, without consulting experts and specialists in the Chernobyl events. There are such specialists in the Chernobyl community, in general, and in our Chernobyl Union of Russia. If the author of the project had presented a sketch to the advisory council, he would have been given feedback without delay, and without interference with the implementation of his plan. In this case, there would have been no disappointing errors, "blunders" that sometimes devalue or reduce the honorable thoughts and ideas.

It is peculiar that members of the NGO doubt the ability of the church to create an icon related to Chernobyl events independently. In the comment, only the members of the organized and official Chernobyl bodies are seen as experts-not the local population or those survivors who are not members of the NGO. This is one example of how Chernobyl artifacts are created, interpreted, and used within a specific vernacular context by a particular group of people that claims authority over the object and determination of its purpose and functions. Besides its assigned meaning and use, the icon communicates additional messages beyond the boundaries of the group when brought into public view and serves as a prototype for further religious images. The depiction of aspects such as gender roles in coping with the disaster on the Chernobyl icons is therefore constantly contested and reformulated.

\section{Conclusion}

In the Russian Orthodox Church, women are often depicted as having an insignificant liturgical role, as they are underrepresented in the official church structure. When focusing on vernacular religion, we often notice 
that women come to the fore of religious life, bringing their concerns to the religious discourse.

In the Chernobyl commemorative culture, people frequently resort to the images of Mary as a mother with a child to convey their concerns regarding the future and reality after the disaster. These images are used to depict multiple levels of the post-Chernobyl reality, from mourning for what is lost (future, health, land, and loved ones) and expression of reproductive fears to resistance to nuclear threat and governmental oppression. The icons of Chernobyl convey the urge for healing and consolation as well as proclaiming the heroism and martyrdom of the liquidators. This made them especially important for the members of the predominantly male Chernobyl survivor unions, who commission the new icons and often claim authority over them.

The Chernobyl icons serve as ambiguous artifacts, which often perpetuate so-called traditional gender roles by denying women's agency, professional involvement, and activism related to the challenges brought about by the explosion. However, the original "Savior of Chernobyl" icon stands out as an exception to this rule by placing women among the active liquidators of the consequences of the catastrophe, depicting them as medical professionals. Nevertheless, this position of women is constantly contested through the creation of subsequent versions of this icon with frequent attempts to move them to the periphery, depicting them as vulnerable victims with their roles limited to mourning, motherhood, and caregiving. Despite the continuous production of new versions, these are not as widespread and influential as the original iconography of "The Savior of Chernobyl."

The religious dimension of the nuclear culture of Chernobyl is easy to neglect. Yet, it provides valuable material for approaching the complex ways in which people react to life-changing historical events. As argued in this chapter, analyzing the visual commemorative culture of religion contributes to the understanding of politically ambivalent events, especially when oral or written narratives are scarce. The icons of Chernobyl reveal how the same religious tradition assigns gender roles differently on its various levels: individual, folk, and official.

\section{Notes}

1 For reasons of anonymity all the informants' names are changed. All translations are by the author.

2 The US title of the same book but in a different translation is Voices from Chernobyl: The Oral History of a Nuclear Disaster (Alexievich 2006).

3 Liquidator is a colloquial term for the civil and military personnel sent to minimize the consequences of the Chernobyl nuclear disaster.

4 It is not an etymological, but phonetic "de-coding" of the Russian word Chernobyl: cherny (black) + byl (true story).

5 It is an attempt to connect the star Wormwood from Revelation 8:10-11 with the translation of the word Chernobyl from Ukrainian, meaning wormwood.

6 The Exclusion Zone is a restricted area around the Chernobyl Nuclear Power Plant. 
7 The icon is known in English alternatively as "Chernobyl Savior," "The Chernobyl Savior," or "Savior of Chernobyl." For copyright reasons, it was not possible to print an image of the icon in this book. The image can, however, be found online (see Archmandrite Sergiy 2016).

8 For copyright reasons, it was not possible to print an image of the icon in this book.

9 LTP is a correctional facility where alcoholics are sent through the local police office if they are disturbing the social order. The alcoholics are treated there through physical labor and medical means.

10 It is unclear-it might be a picture of the icon made by Sister Angelina Heuser.

11 The website of the Union "Sojuz 'Chernobyl' Rossii” is: http://www.souzchernobyl.ru/. The letter, signed by V. Maleev, is no longer available online. The author is in possession of a copy of the letter's content, extracted August 15, 2015.

\section{Bibliography}

Aho, James A. 1989. “'I Am Death. Who Shatters Worlds': The Emerging Nuclear Death Cult." In A Shuddering Dawn: Religious Studies and the Nuclear Age, edited by Ira Chernus and Edward Tabor Linenthal, 49-69. Albany: State University of New York Press.

Alexievich, Svetlana. 2016. Chernobyl Prayer: A Chronicle of the Future. Translated by Anna Gunin and Arch Tait. London: Penguin Modern Classics. Kindle edition.

Alexievich, Svetlana. 2006. Voices from Chernobyl: The Oral History of a Nuclear Disaster. Translated by Keith Gessen. Quebec City: Braille Jymico Inc.

Andreev, Jurij. 2010. “Ikona 'Chernobyl'skij Spas' i kanonichnost'.” Ukraïna Pravoslavna, March 1. Accessed July 4, 2019. http://pravoslavye.org.ua/2010/03/ yuriy_andreev_ikona_chernobilskiy_spas_i_kanonichnost/.

Bashilov, A. V. 2013. Belarus' $i$ Chernobyl': 27 let spustiāa. Minsk: Institut radiologii.

Bowman, Marion. 2004. "Phenomenology, Fieldwork and Folk Religion.” In Religion: Empirical Studies, edited by Steven Sutcliffe, 3-18. Farnham: Ashgate.

Bowman, Marion, and Ülo Valk, eds. 2012. Vernacular Religion in Everyday Life: Expressions of Belief. Sheffield: Equinox.

Boyer, Paul S. 1985. By the Bomb's Early Light: American Thought and Culture at the Dawn of the Atomic Age. New York: Pantheon.

Danilenko, N. V. 2011. We Feel It: Catalouge of Children's Drawings "Chernobyl and Belarus: Past, Present, Future." Minsk: Institut Radiologii.

Hogg, Jonathan. 2016. British Nuclear Culture: Official and Unofficial Narratives in the Long 20th Century. London: Bloomsbury Academic.

Kirillova, Regina, and Aleksej Iskandirov. 2014. "V Kazani Vystavili Pervuju V Rossii Ikonu, Posvjashhennuju Chernobylju.” Komsomol'skaya Pravda, May 20, 2014. Accessed May 20, 2019. http://www.kp.ru/online/news/1739548/.

Kirkevich, Ales'. 2017. “'Zolata partyi': Top-6 rjelikvijay̆ BNF.” Novy Chas Online, December 10. Accessed February 15, 2018. https://novychas.by/palityka/ zolata-partyi-top-6-relikvijau-bnf.

Kotrelev, Fedor, and Konstantin Shapkin. 2007. "Chernobyl': Zona Zhizni.” Pravoslavnyj Zhurnal "Neskuchnyj Sad” 7 (27), July 13. Accessed May 27, 2019. http://www.nsad.ru/articles/chernobyl-zona-zhizni. 
Morton, Timothy. 2010. The Ecological Thought. Cambridge: Harvard University Press.

Nasrallah, Rima, Martien E. Brinkman, Heleen Murre-van den Berg, and Marcel Barnard. 2016. "Which Mary? Eastern Christian Women Bringing Their Mary into the Lebanese Protestant Church.” Mission Studies 33 (1): 4-25. doi:10.1163/15733831-12341431.

Phillips, Sarah D. 2002. "Half-Lives and Healthy Bodies: Discourses on Contaminated Food and Healing in Postchernobyl Ukraine." Food and Foodways 10 (1-2): 27-53.

Pogosjan, Jelena, and Maria Smorzhevskih. 2002. “Ja Devu v solnce zrju stojashhu...': obraz apokalipsicheskoj Zheny v russkoj oficial'noj kul'ture 16951742 gg." Studia Russica Helsingiensia et Tartuensia VIII: 9-37. Accessed May 20, 2019. http://www.ualberta.ca/ pogosjan/public/public2002_deva.html.

Primiano, Leonard Norman. 2012. "Afterword: Manifestations of the Religious Vernacular: Ambiguity, Power and Creativity." In Vernacular Religion in Everyday Life: Expressions of Belief, edited by Marion Bowman and Ülo Valk, 382-394. Sheffield: Equinox.

Primiano, Leonard Norman. 1995. "Vernacular Religion and the Search for Method in Religious Folklife." Western Folklore 54 (1): 37-56.

Pugacheva, Emma. 1991. Chernaja byl': Serija kartin: 1988-1989 M. Savitsky. Art catalogue. Minsk: Izdatel'sko-poligraficheskij centr Minskogo oblastnogo otdelenija Sovetskogo fonda kul'tury.

Religious Information Service of Ukraine. 2011. "Chernobyl God's Punishment for 'Sinners': Russian Church.” RISU: Religious Information Service of Ukraine, April 28, 2011. Accessed May 20, 2019. https://risu.org.ua/en/index/all_news/ orthodox/orthodox_world/42081/.

Romashko, Elena. 2016. "Religion and 'Radiation Culture': Spirituality in a PostChernobyl World.” Material Religions, June 1, 2016. Accessed May 20, 2019. https://jugaad.pub/religion-and-radiation-culture-spirituality-in-a-postchernobyl-world/.

Sergiy (Yakushin), Archmandrite. 2016. "Chernobyl'skie chudesa." Pravoslavie. ru, April 26, 2016. Accessed May 20, 2019. https://pravoslavie.ru/92817.html.

Vakhromeev, Philaret. 1994. "Pastyrskie razmyshlenija." Grodnenskie eparhial'nye vedomosti 5 (24): 12-13. 